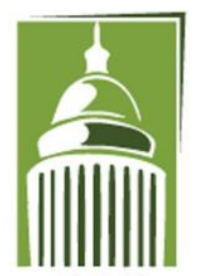

AR F

\section{Global Proceedings Repository \\ American Research Foundation}

ISSN 2476-017X

Available online at http://proceedings.sriweb.org

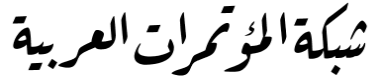

http://arab.kmshare.net/

The Ninth International Scientific Academic Conference

Under the Title "Contemporary trends in social, human, and natural sciences"

$$
\begin{aligned}
& \text { المؤتمر العلمي الاكاديكي الدولي التاسع - (لمع } \\
& \text { تحت عنوان "الاتحاهات المعاصرة في العلوم الاجتماعية، الانسانية، والطبيعية" } \\
& 17 \text { - } 18 \text { يوليو - تموز } 2018 \text { - اسطنبول - تركيا }
\end{aligned}
$$

http://kmshare.net/isac2018/

\title{
Modification of diclofenac with some substitutes to increase anti-inflammatory activity and to be more selective to $\mathrm{COX}-2$
}

\author{
Bilal J. Mohammed ${ }^{a}$, Hadil J. Maayouf ${ }^{b}$ \\ a Anbar University, College of Education for Women, Anbar Iraq \\ b_ji_55@yahoo.com \\ ${ }^{\mathrm{b}}$ Anbar University, the college of science, Anbar, Iraq \\ j.mhadeel@yahoo.com
}

\begin{abstract}
In the present study, we prepared four amide derived from anti- inflammatory drug diclofenac sodium (2-[(2,6dichlorophenyl)amino] benzeneacetic acid, monosodium salt). Amides synthesized by two steps: first step preparation anhydride from sodium diclofenac by reacting two molecules of diclofenac acid in the presence of one equivalent of dicyclohexyl carbodiimide (DCC) and then transferred it to different amides by reacting with different amines (sulphanilamide, O-nitroaniline, 2,4 dinitroaniline, P-bromoaniline) as well as the identification and characterization of products by FT-IR, 1HNMR and13C NMR spectroscopy, and C.H.N elements data. The efficacy evaluation was assessed as analgesics using hot plate test and to test its effectiveness as inhibitors of COX enzyme and their selectivity within the body of the organism In vivo. Acute anti-inflammatory activity of the synthesized final compounds was evaluated in mice using egg-white induced edema model of inflammation in a dose equivalent to $(1.5 \mathrm{mg} / \mathrm{Kg}, 3 \mathrm{mg} / \mathrm{kg}, 6 \mathrm{mg} / \mathrm{kg})$ of diclofenac. The results indicate that the compounds are effective inhibitors of cyclooxygenase, because the pain caused by the effectiveness of cyclooxygenase and the most effectiveness compound was [2-(2-(2,6-dichlorophenylamino) phenyl)-N-(4-sulfamoylphenyl)acetamide]
\end{abstract}




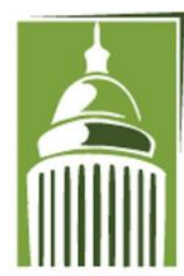

AR F

\section{Global Proceedings Repository \\ American Research Foundation}

ISSN 2476-017X

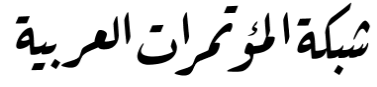

http://arab.kmshare.net/

Available online at http://proceedings.sriweb.org

which produced from reaction between Diclofenac and sulphanilamide. An inflammation was introduced in the rats using carrageenan and measured PGE2 level in plasma blood. and showed a significant reduction in the level of prostaglandin. The results of this experiment showed that some prepared compounds has higher activity of inhibition than the parent medication, and give a good picture of selectivity of inhibition of COX -2 by comparing with celecoxib. Through a molecular docking studies of prepared compounds with the active site of the enzyme COX-1 and COX-2, it was found that the compounds have affinity for the enzyme COX2 more than their affinity to COX-1 which support selectivity As a result of this study, it was shown that converting the carboxyl group of diclofenac, which is well known as an anti-inflammatory agent to an amide group, preserves or increases inflammation activity and analgesic activity by inhibiting cyclooxygenase enzymes and compounds showing more ratio of selectivity against COX-2.

Keywords: diclofenac, cyclooxygenase, anti-inflammatory, carrageenan, analgesic, prostaglandin.

\section{Introduction}

Cyclooxygenase (COX) is an intracellular enzyme that stimulates the addition of two oxygen molecules to unsaturated fatty acids, The most biologically relevant of these is Arachidonic acid (AA), to prostaglandin G2 (PGG2)( Smith et al.,1996). PGG2 is then reduced to prostaglandin H2 (PGH2) by Special enzymes for different types of prostacendins, which are biologically active fats and act as topical autocrine or paracrine hormones, include PGE2, PGF2 $\alpha$, PGD2, PGI2, TXA2 (Turini and DuBois, 2002; Ivković, 2010). The main cause of inflammation is the overproduction of prostaglandins, which are synthesized by Cyclooxygenase enzymes (Somvanshi et al., 2007). COXs are present in three isoforms: COX1, COX2 and COX3.

COX-1 as the constitutive form is usually involved in maintaining the physiological conditions of Variety of these processes includes gastrointestinal mucosa protection, platelet aggregation, maintainance of vascular homeostasis, maintain normal renal function in a compromised kidney and reproduction While COX-2 is the stimulated form of the enzyme stimulated by a number of inflammatory stimuli such as Proinflammatory Cytokines and tumor promoters in a number of pathological conditions such as inflammation and cancer but also participates in a number of physiological processes. COX-3 was recently discovered, an isoenzyme of COX-1, found in higher concentrations in the brain and heart, and may explain the mechanism of action of antipyretic analgesics(Smith and Langenbach, 2001; Sharma et al.,2012; Sharma,2012; Chandrasekharan, 2002 ).

Cyclooxygenase enzymes are the main target of non-steroidal anti-inflammatory drugs (NSAIDs) such as aspirin, naproxen and ibuprofen, (NSAIDs) have gastrointestinal side effects because they inhibit both isoforms so that chronic use of aspirin and (NSAIDs) gives rise to serious iatrogenic effects in the gastrointestinal tract in a significant proportion of the patient population for long periods of time, causing damage to the gastrointestinal mucosa(Fitzgerald and Patrono, 2001). The study of $X$ - ray crystals has shown that COX-2, COX-1 was similar in structural structure, but there were important difference, the exchange of valine in COX-2 at positions 434 and 523 in place of isoleucine in COX-1, opening an additional pocket result in the inhibitor binding site in COX-2, being larger than that in COX-1 (Otto and Smith, 1995; . Luong et al,1996; Guo, 1996). The researchers used this difference in size for the active site of COX-2 to shed much light on the mechanism of the selective Cox-2 inhibitors to eliminate the side effects associated with the use 


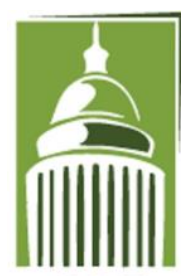

AR F

\section{Global Proceedings Repository \\ American Research Foundation}

ISSN 2476-017X

Available online at http://proceedings.sriweb.org

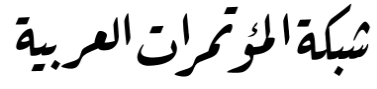

http://arab.kmshare.net/

of traditional (NSAIDs). These inhibitors are celecoxib, rofecoxib, parecoxib but some of it cause serious side effects of the heart, was withdrawn from the market(Rao and Knaus, 2008; Smith et al., 2000; Mukherjee et al., 2001; FitzGerald, 2004).

Drug design is an important tool in the field of medicinal chemistry where new compounds are synthesized by molecular or chemical manipulation of the lead moiety in order to produce highly active compounds with minimum steric effect (Cavasotto and Abagyan, 2004). the use of computers to predict the binding of libraries of small molecules to known target structures is an increasingly important component in the drug discovery process(Schoichet 2004, Koppen 2009). There is a wide range of software packages available for the conduct of molecular docking simulations like, AutoDock, GOLD, FlexX4. molecular docking one method for exploring the interactions between a ligand and a protein. Although both synthesis and crystallography can sometimes be quite unpredictable and time-consuming, the method may be viable for small collections of ligands. If synthesis or crystallization fails, or if the aim is to screen many ligands for binding to the protein, computational molecular docking is often the method of first choice, and has become popular within both academia and industry(Collignon et al., 2011).

The hypothesis of the research is that if the carboxylic group of traditional (NSAIDs) have been manipulated and prepared of larger molecules they will become selective inhibitors of. COX-2. The aim of the study is to prepare a series of diclofenac compounds and to test their efficacy as inhibitors of cyclooxygenase enzymes and to examine them if they have selective efficacy against COX-2.

\section{Materials and Methods}

\section{Molecular Modeling}

The three-dimensional crystalline structure of COX-1 (PDB code: 1Q4G) and COX-2 (PDB code: 1CX2) were downloaded from online Protein Data Bank (PDB) and the 2D structure of the compounds were drown using 11.0 Ultra ChemBioDraw software and then MOE 2009.10 software was used for molecular docking. Hydrogens were added to all COX enzymes PDB crystal structures and Water molecules and ligands were removed and one of the enzyme units was removed to maintain the active site only. flurbiprofen and SC-558 which were co-crystallized in the structure of $1 \mathrm{EQH}$ and $1 \mathrm{CX} 2$, respectively, were extracted and redocked into their original binding pockets. synthesized compounds docked into the pre- defined binding sites of COX-1 and COX-2 Which is within the crystalline structure.

\section{Materials}

Diclofenac, Carboxymethyl cellulose (CMC), Dimethylsulfoxide (DMSO), Petroleum ether, Ethyl acetate were purchased from Sigma-Aldrich(Germany), O-Nitroaniline, 2,4- di chloro aniline,P-bromo aniline, zinc dust, Glacial acetic acid, bicarbonate sodium, sodium chloride BDH (England), tetrahydrofuran (THF) from Reidel-Dehean (Germany), Dicyclohexylcarbodiimide (DCC), Dioxane 1,4 from HiMedia (India)

\section{Apparatus}

Melting points were determined on a Stuart Melting Point Apparatus SMP3 and were uncorrected. IR spectra were recorded on a FTIR Perkin Elmer Paragon 500 spectrometer. IR spectra were recorded on Fisher-100 FTIR spectrophotometer (Japan) as a KBr film in the range (400-4000)cm-1 in the College of Education for woman/University of ANBAR. 1H- and 13C-NMR spectra were recorded on a Bruker $500 \mathrm{MHz}-$ Avance III spectrometer in Jordan, CHN microanalysis was done by using EURO EA (ELEMENTAL ANALYSER) in Mustansiriyah University. 


\section{Global Proceedings Repository \\ American Research Foundation}

ISSN 2476-017X

Available online at http://proceedings.sriweb.org
شبكة المؤومرات العربية

http://arab.kmshare.net/

\section{Synthesis}

Diclofenac sodium obtained from the SDI Company, Iraq was reacted with(DCC) to produce anhydride diclofenac was further reacted with different amines The general routes outlined in scheme 1 were used to synthesized the target compounds and their intermediates. Amide prodrugs so synthesized were characterized with the help of elemental analysis and spectroscopic techniques such as: FT-IR, 1H-NMR, 13C-NMR.

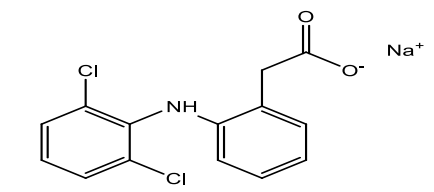

2
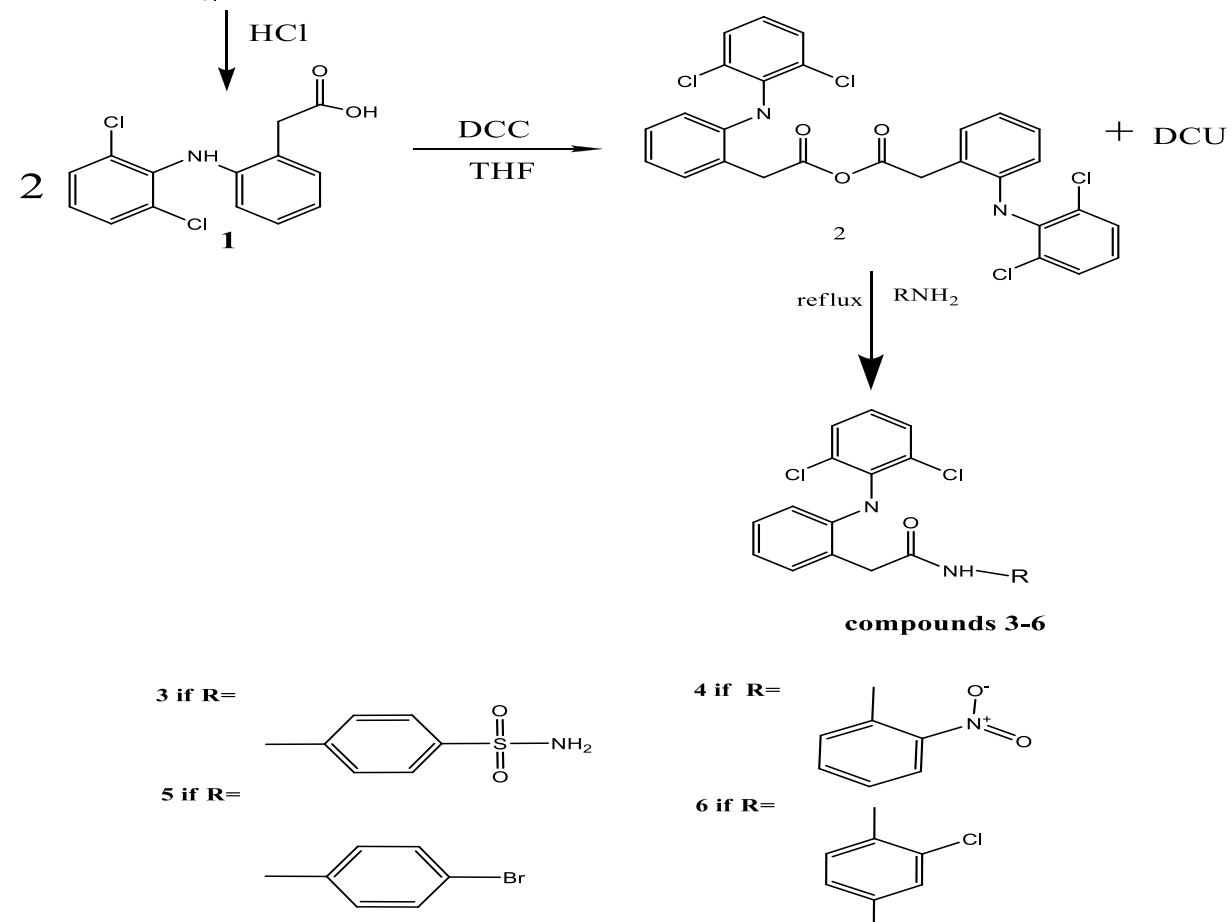

4 if $R=$

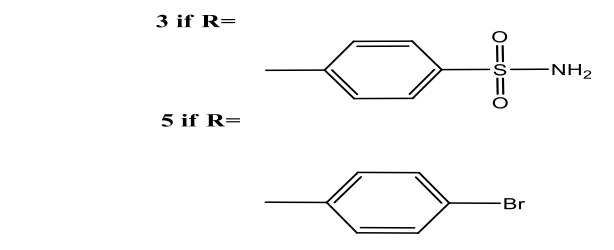

6 if $\mathbf{R}=$

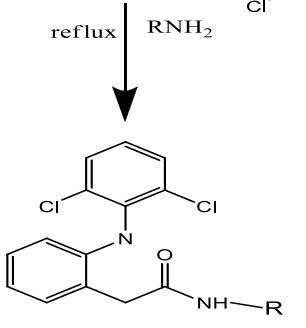

compounds 3-6

DCU:dicyclohexyl urea
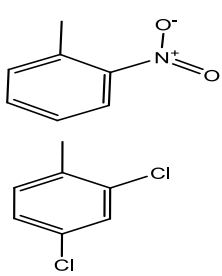

Scheme 2: Synthesis of compounds 3, 4, 5 and 6

\section{Synthesis2-(2-(2,6- dichlorophenylamino)phenyl)acetic acid}

The free acid was prepared for use in possible synthetic routes to other salts of diclofenac. ( $5 \mathrm{~g}$ ) of sodium diclofenac salt was dissolved in $500 \mathrm{ml}$ of distilled water. The solution was acidified with $1 \mathrm{M} \mathrm{HCl}$ until a white precipitate of diclofenac acid was observed. The precipitate was filtered, washed with distilled water and dried in vacuum apparatus. 


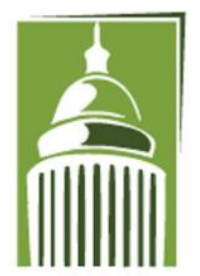

AR F

\section{Global Proceedings Repository \\ American Research Foundation}

ISSN 2476-017X

Available online at http://proceedings.sriweb.org

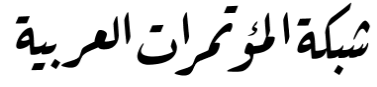

http://arab.kmshare.net/

Synthesis 2-(2-(2,6-dichlorophenylamino)phenyl)acetic anhydride

Diclofenac acid(5g, $0.0168 \mathrm{~mol})$ was dissolved in tetrahydrofuran (THF) $(40 \mathrm{ml})$, and then dicyclohexyl carbodiimide (DCC) $(1.74 \mathrm{~g}, 0.008 \mathrm{~mol})$ was added. The reaction mixture was stirred continuously at room temperaturefor 4 hours, where a white precipitate of dicyclohexylurea (DCU) was formed which was then removed by filtration. The solvent was evaporated under vacuum to yield compound (1) as a white powder(Banerjee and Amidon, 1981). IR ( $\left.\mathrm{cm}^{-1}\right)$ : 1807 and 1727 of anhydride (symmetric and asymmetric), $1394,1265,1176 \quad \mathrm{C}-(\mathrm{C}=\mathrm{O})-\mathrm{O}-(\mathrm{C}=\mathrm{O})-\mathrm{C}$ of anhydride.

\section{General Procedure for Synthesis of the Final Compounds 3-6}

Compound $2(2.655 \mathrm{~g}, 0.006 \mathrm{~mol})$, amine $(0.012 \mathrm{~mol})$, zinc dust $(0.011 \mathrm{~g})$, glacial acetic acid $(1.1 \mathrm{ml}, 0.0192$ $\mathrm{mol})$ and dioxane $(40 \mathrm{ml})$ were placed in a flask, equipped with refluxed condenser, boiling stones were added. The reaction mixture was refluxed gently for 2 hour. The solvent was evaporated under vacuum, the residue was dissolved in ethyl acetate, washed with $\mathrm{NaHCO} 3(10 \%, 2 * 50 \mathrm{ml}), \mathrm{HCl}(1 \mathrm{~N}, 2 * 50 \mathrm{ml})$ and distilled water $(2 * 50 \mathrm{ml})$, and filtered over anhydrous magnesium sulfate. The filtrate is evaporated under vacuum to give the product. The crystallization is carried out by dissolving the compound in ethyl acetate and petroleum ether $\left(60{ }^{\circ} \mathrm{C}\right)$ is added to the filtrate until turbidity take place and it is kept in cold place for 2 hour. The mixture is filtered while it is cold and the precipitate is collected to give final compounds (Furniss et al., 1989) their characterization and physical data are presented in table 1

2-(2-(2,6-dichlorophenylamino)phenyl)-N-(4-sulfamoylphenyl)acetamide (3) IR (cm-1): $3322 \quad(\mathrm{~N}-\mathrm{H})$ of secondary amide, 1,693(C=O) of secondary amide, 1,577, 1504, 1450 (aromatic), 1296 and $1157(\mathrm{O}=\mathrm{S}=\mathrm{O})$ of sulfone. 1H NMR: $\delta$ 2.5(S,2H,-NH2),3.7(s,2H,CH2) ,5.9 (bs,1H,CONH-),6.2-7.5(m,11H,ArH). 13C NMR: $\delta 40(-\mathrm{CH} 2-)$, , 106-131(ArC), 143(ArC- NH-),137( ArC- Cl), 173.8(-NHCO-).

2-(2-(2,6-dichlorophenylamino)phenyl)-N-(2-nitrophenyl)acetamide(4)IR $\quad(\mathrm{cm}-1): 3313 \quad(\mathrm{~N}-\mathrm{H})$ of secondary amide, $1651(\mathrm{C}=\mathrm{O})$ of secondary amide, 1576, 1507, 1443 (aromatic), $1329(\mathrm{O}=\mathrm{N}-\mathrm{O}) \quad 1 \mathrm{H}$ NMR:,3.7(s,2H,CH2) $\quad, 5.9 \quad(\mathrm{bs}, 1 \mathrm{H}, \mathrm{CONH}-), 6.2-8.2(\mathrm{~m}, 11 \mathrm{H}, \mathrm{ArH}) . \quad$ 13CNMR: $\quad \delta 38 \quad(-\mathrm{CH} 2-), 106-$ 131(ArC), 143(ArC-NH-), 137(ArC-Cl), 146(ArC-NO2), 173.8(-NHCO-).CHNS calculated $\left(\mathrm{C}_{20} \mathrm{H}_{15} \mathrm{Cl}_{2} \mathrm{~N}_{3} \mathrm{O}_{3}\right)$ : C, 57.71; H, 3.63; N, 10.09; found: C, 58.62; H, 3.23; N,9.58.

N-(2,4-dichlorophenyl)-2-(2-(2,6-dichlorophenylamino)phenyl)acetamide (5) IR (cm-1): 3323 (N-H) of secondary amide, $1694(\mathrm{C}=\mathrm{O})$ of secondary amide, $1577,1505,1450$ (aromatic), $1 \mathrm{H} \mathrm{NMR:} \delta 3.7(\mathrm{~s}, 2 \mathrm{H}, \mathrm{CH} 2)$ ,7.25 (bs,1H,CONH-),6.3-7.75(m,10H,ArH). 13C NMR: $\delta 38$ (-CH2-), 116-143(ArC),143(ArC-NH-), 173.84(-NHCO-).

N-(4-bromophenyl)-2-(2-(2,6-dichlorophenylamino)phenyl)acetamide (6) IR (cm-1): 3323 (N-H) of secondary amide, 1694(C=O) of secondary amide, 1577, 1504, 1450 (aromatic), 1329 and 1507 13C NMR: $\delta 38$ (-CH2-), 108-143(ArC),143(ArC-NH-), 173.69(-NHCO-) CHNS calculated $\left(\mathrm{C}_{20} \mathrm{H}_{15} \mathrm{BrCl}_{2} \mathrm{~N}_{2} \mathrm{O}\right): \mathrm{C}$, 53.36; H, 3.36; N, 6.22; found: C, 53.96; H, 3.16; N,5.82. 


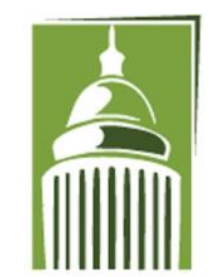

AR F

\section{Global Proceedings Repository \\ American Research Foundation}

ISSN 2476-017X

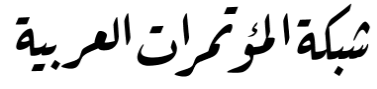

http://arab.kmshare.net/

Available online at http://proceedings.sriweb.org

Table (1): The characterization and physical data of the compounds

\begin{tabular}{|l|l|l|l|l|l|}
\hline compound & $\begin{array}{l}\text { Empirical } \\
\text { formula }\end{array}$ & $\begin{array}{l}\text { Molecular } \\
\text { weight }\end{array}$ & Description & \% yield & $\begin{array}{l}\text { Melting } \\
\text { point } \\
\text { Observed }\end{array}$ \\
\hline 1 & $\mathrm{C}_{14} \mathrm{H}_{11} \mathrm{Cl}_{2} \mathrm{NO}_{2}$ & 296.1 & white & $99 \%$ & $283-284$ \\
\hline 2 & $\mathrm{C}_{28} \mathrm{H}_{20} \mathrm{C}_{14} \mathrm{~N}_{2} \mathrm{O}_{3}$ & 574.3 & white & $65 \%$ & $106-108$ \\
\hline 3 & $\mathrm{C}_{20} \mathrm{H}_{17} \mathrm{Cl}_{2} \mathrm{~N}_{3} \mathrm{O}_{3} \mathrm{~S}$ & 450.3 & white & $43 \%$ & 171 \\
\hline 4 & $\mathrm{C}_{20} \mathrm{H}_{15} \mathrm{Cl}_{2} \mathrm{~N}_{3} \mathrm{O}_{3}$ & 416.3 & yellow & $47 \%$ & 166 \\
\hline 5 & $\mathrm{C}_{20} \mathrm{H}_{14} \mathrm{Cl}_{4} \mathrm{~N}_{2} \mathrm{O}$ & 440.1 & white & $44 \%$ & $171-173$ \\
\hline 6 & $\mathrm{C}_{20} \mathrm{H}_{15} \mathrm{BrCl}_{2} \mathrm{~N}_{2} \mathrm{O}$ & 450.2 & white & $45 \%$ & $160-162$ \\
\hline
\end{tabular}

\section{Pharmacology}

\section{cyclooxygenase enzymes inhibition}

the inhibitory effect of prepared compounds has been studied by studying its anti-pain and anti-inflammatory effect In the body of the organism.

Albino mice of either sex weighing $(27 \pm 2 \mathrm{~g})$ were supplied by the animal house of the College of Science, University of Anbar under standardized conditions (12 light-12 dark cycle) for 7 days for acclimatization. Animals were fed commercial chaw and had free access to water ad libitum. In both the hot- plate test and egg-white induced edema model the animals were randomly divided into groups (each group consist of 3 mice) as follows:

group A: served as control and treated with the vehicle (DMSO $0.03 \mathrm{ml}$ ).

group B treated with aspirin(reference agent) in a dose of $100 \mathrm{mg} / \mathrm{kg}$ suspended in DMSO.

group C: treated with sodium diclofenac (reference agent) in a dose of $3 \mathrm{mg} / \mathrm{kg}$ suspended in DMSO.

three groups for each compound treated with tested compounds 3, 4,5 and 6 respectively in a three doses equivalent to $(1.5 \mathrm{mg} / \mathrm{Kg}, 3 \mathrm{mg} / \mathrm{kg}, 6 \mathrm{mg} / \mathrm{kg})$ of sodium diclofenac

\section{Anti-inflammatory activity}

The anti-inflammatory activity of the tested compounds was studied using egg-white induced edema model (Vogel and Goethe, 2002). The drugs or the vehicle were administered i.p. at time zero and acute inflammation was induced by a subcutaneous injection of $0.05 \mathrm{ml}$ of undiluted egg-white into the planter side of the left hind paw of the mice at time 30 minutes. The paw thickness was measured by vernier at three time intervals (30,90, and 150minutes) after vehicle or drugs administration. edema is observed and percentage of reduction in oedema is calculated using the following formula:

$\%$ inhibition $=100[(\mathrm{Vc}-\mathrm{Vt}) / \mathrm{Vc}]$

Where, $\mathrm{Vt}=$ Oedema volume in the drug treated group

$\mathrm{Vc}=$ Oedema volume in the control group(Kamble PS et al., 2012). 


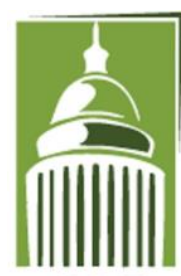

AR F

\section{Global Proceedings Repository \\ American Research Foundation}

ISSN 2476-017X

Available online at http://proceedings.sriweb.org

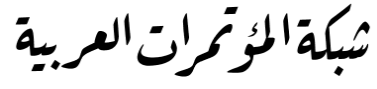

http://arab.kmshare.net/

\section{Analgesic activity}

The analgesic activity of the synthesized compounds was evaluated by using Hot plate method. The hot plate test was conducted on mice according to the method described by Woolfe and MacDonald ( Woolfe and McDonald 1994). The mice were placed on the hot plate, maintained at constant temperature of $55 \pm 0.5^{\circ} \mathrm{C}$ and the latency of nociceptive response such as licking and jumping[the time from reaching the hot plate until it first licks a paw and try to jump out] were measured before and administrating the drug at time 30 second and 60 second after. Acute - off time of 45 second was selected to prevent tissue damage(MalekiDizaji et al., 2007). Finally the reaction time was noted and compared with the control group.

\section{Measurement of plasma PGE2 concentration}

Wistar rats of both sexes $(150 \mathrm{~g}-200 \mathrm{~g})$ were randomly assigned to groups: two groups (control 1, control 2 ) : treated with the vehicle CMC 5\% ( $0.5 \mathrm{ml}$ i.p) one group : treated with diclofenac sodium in a dose $1(0.5 \mathrm{ml} \mathrm{ip})$ three groups for each compound each group treated with one dose ( $0.5 \mathrm{ml}$ i.p ) One percent $(\mathrm{w} / \mathrm{v})$ carrageenin in $0.9 \%$ saline, $0.1 \mathrm{ml}$, was used to induce inflammation in the right hind paw of one group of control rats (control 2) and the treated groups, one hour after treatment (i.p). The carrageenin-treated control group (control 2) served as positive control. One hour after the injection of carrageenan the rats were anaesthetized with ether, and dissected to expose the heart. Blood samples were collected separately from each animal by cardiac puncture and immediately put into tubes containing EDTA. The blood samples were centrifuged at 10,000 rpm for $15 \mathrm{~min}$, and the plasma decanted and stored at $-4^{\circ} \mathrm{C}$ (Prempeh and MensahAttipoe, 2008).

\section{Statistical analysis}

The results were statistically analyzed using Microsoft Excel 2007 in the analysis of ANOVA variables. The mean difference was found at a probability level less than $0.01(\mathrm{P}<0.01)$.

\section{Results and Discussion}

Because the cyclooxygenase enzymes are responsible for the production of prostaglandin that mediate pain and inflammation, inflammation and pain are a indicate of the activity of cyclooxygenase enzymes (COX2 ), the inhibitory effect of prepared compounds has been studied by studying its anti-pain and antiinflammatory effect in vivo. Rodents were used for testing because the mammalian immune system is very similar across different species. chemical mediator of inflammation of rodents have a high similarity to their human counterparts so rodent inflammation models are invaluable in investigating inflammatory mechanisms and testing new anti-inflammatory treatments that may be applicable to human(Winter et al., 1963).

\section{egg-white induced paw edema}

Many irritant agents have been used in the paw-edema method like dextran, histamine, egg-white and carrageenan solution(Amresh et al., 2007) .Among the many methods used for the evaluation of newly synthesized anti-inflammatory compounds,, one of the most commonly employed techniques is based upon the ability of such agents to inhibit the edema produced in the hind paw of the mice after injection of an irritant agent (Winter et al., 1962). the intr-aplanter injection of egg-white into mouse hind paw induces a progressive edema. diclofenac sodium and aspirin was used as a reference compound of known antiinflammatory activity profile.

After administration of the tested compounds and solvent used by i.p injection at time 0 , the infection was induced by injection of egg-white at time $30 \mathrm{~min}$. The thickness of the hand was measured by vernier at time 


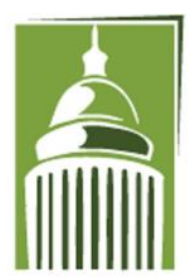

AR F
Global Proceedings Repository

American Research Foundation

ISSN 2476-017X

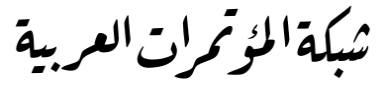

http://arab.kmshare.net/

Available online at http://proceedings.sriweb.org

(30, 90, $150 \mathrm{~min})$. The percentage of inhibition were used as an indicator of the effectiveness of compounds). All tested compounds effectively limited the increase in paw edema. The \% of inhibition increases with increased dose Of the compound as well as increasing the $\%$ of inhibition with the increase of time as shown in the following in Figures

Figure 1: Effect of Control, Compounds 3 - 6 on egg-white induced paw edema in mice (dose $1.5 \mathrm{mg} / \mathrm{kg} \mathrm{of}$ diclofenac sodium)

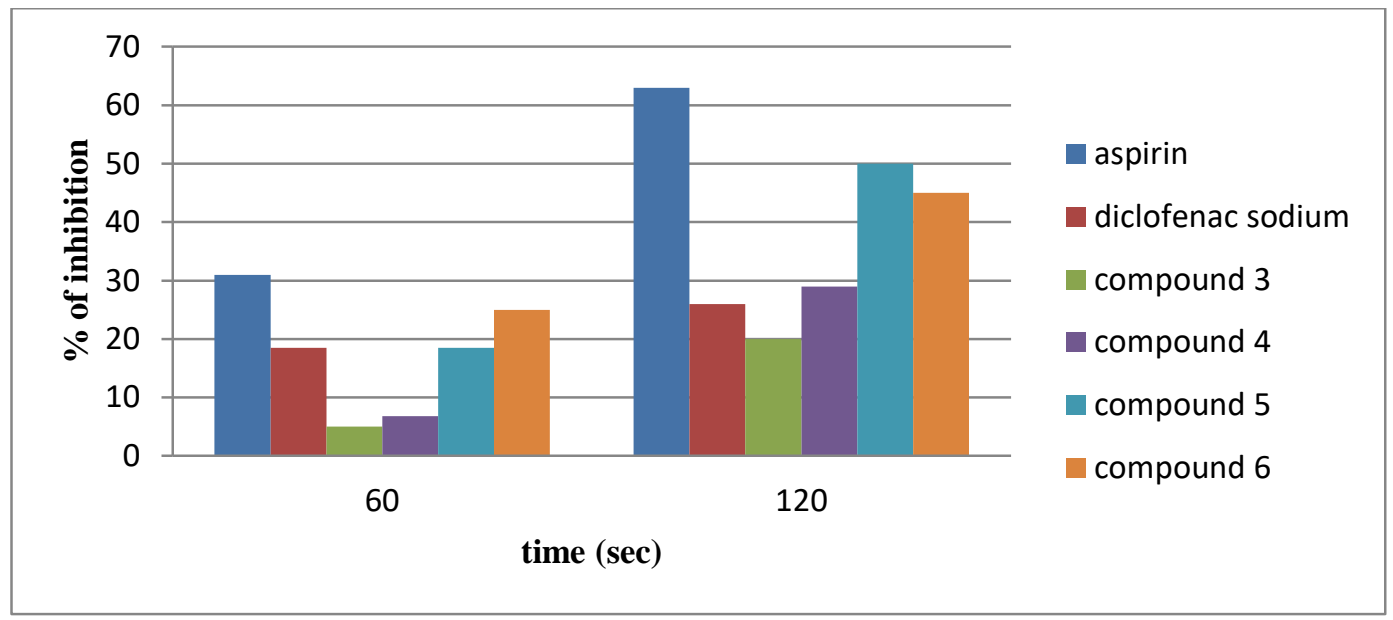

Figure 2: Effect of Control, Compounds 3 - 6 on egg-white induced paw edema in mice (dose $3 \mathrm{mg} / \mathrm{kg} \mathrm{of}$ diclofenac sodium)

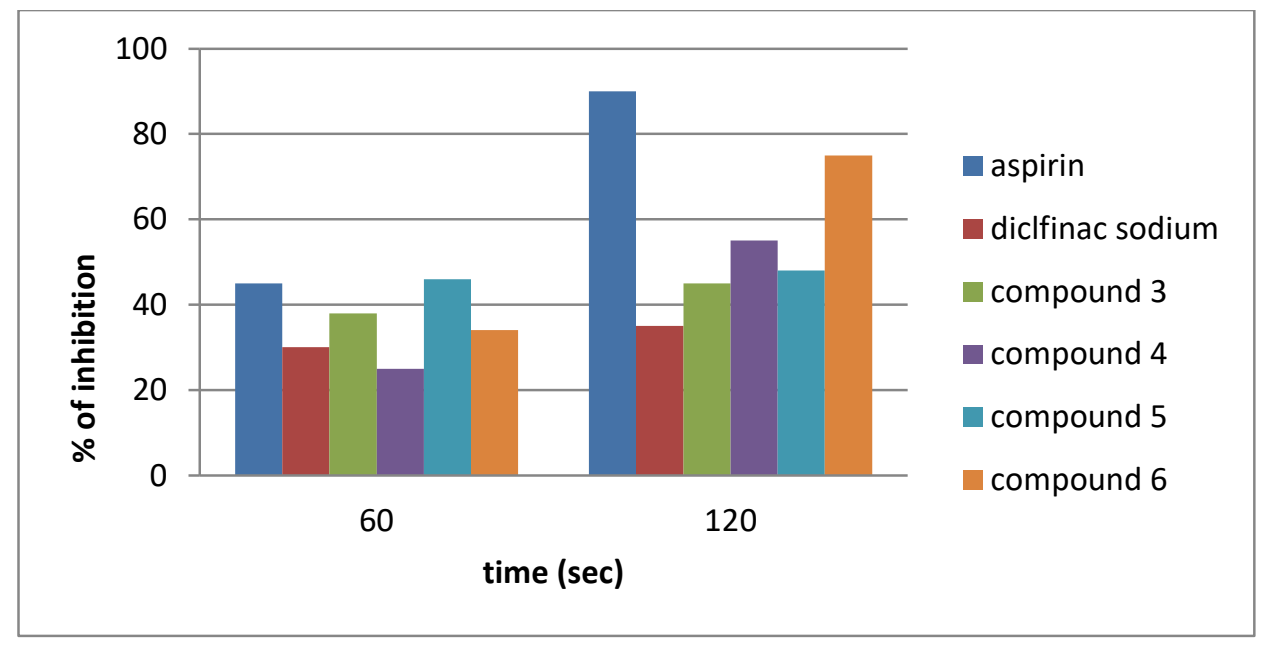




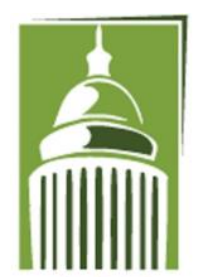

A R F

\section{Global Proceedings Repository \\ American Research Foundation}

ISSN 2476-017X

Available online at http://proceedings.sriweb.org

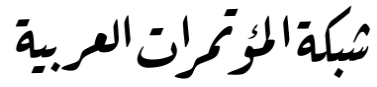

http://arab.kmshare.net/

Figure 3: Effect of Control, Compounds 3 - 6 on egg-white induced paw edema in mice (dose $3 \mathrm{mg} / \mathrm{kg} \mathrm{of}$ diclofenac sodium)

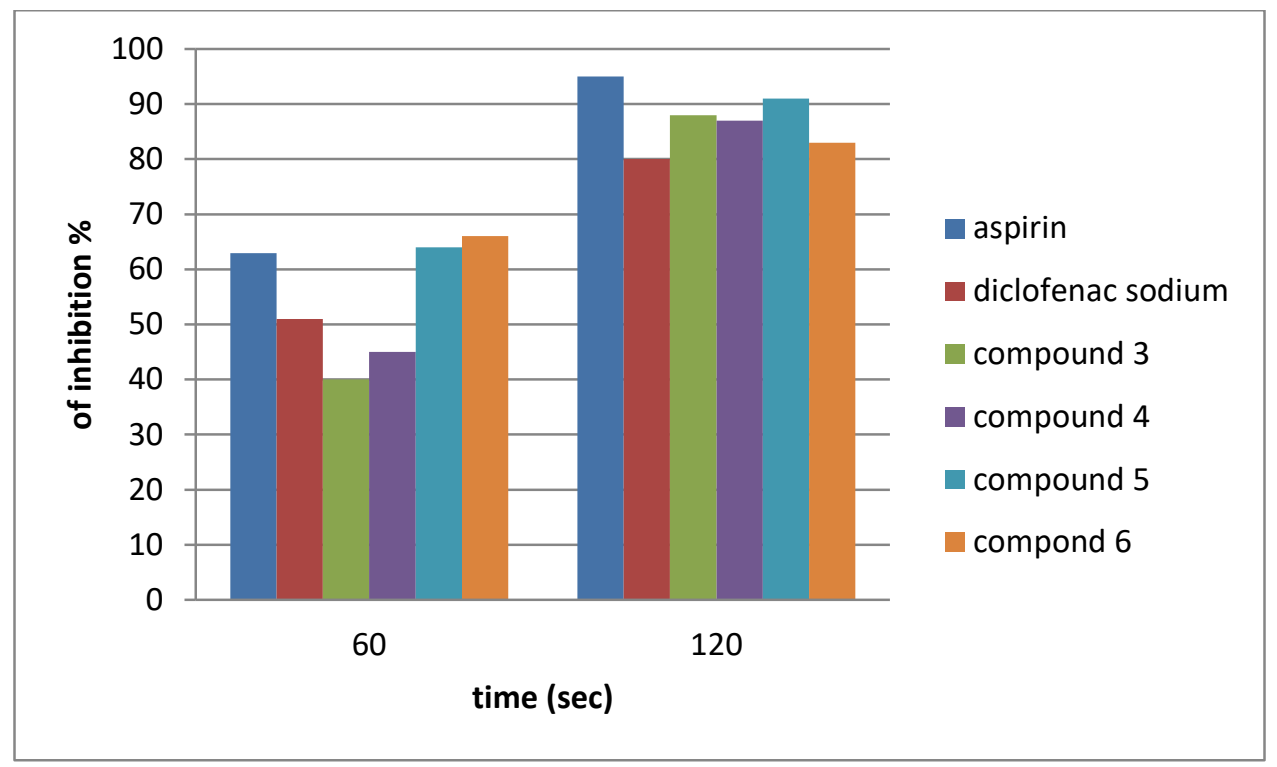

In this study, Thermal painful stimuli was used to test the efficacy of compounds prepared as analgesics. This test was proven even in the case of deprivation of motor performance(Plummer et al., 1996)., the release of arachidonic acid via cyclooxygenase and prostaglandin synthesis plays a role in the nociceptive mechanism. Results of the present study show that the combination of amine p- Bromo-anline ,2,4dichloro-anline, 2 nitroanline, sulfonilamide with diclofenac maintained its effectiveness as analgesics and showed differences between groups which treated with different concentrations where the effect increases with the increase in the dose given to the animal. No significant differences were observed during the increase in time, but a reduction in the effect was observed at time 60 for time 30 in the first dose and the third dose of diclofenac sodium. This effect might be due to inhibition of the synthesis of prostaglandin E2. 


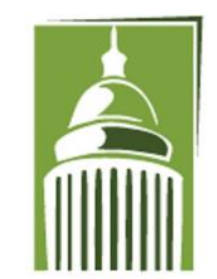

AR F

\section{Global Proceedings Repository \\ American Research Foundation}

ISSN 2476-017X

Available online at http://proceedings.sriweb.org

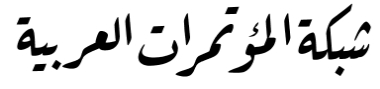

http://arab.kmshare.net/

Table 2: Effect of Control, Compounds 3 - 6 on hot plate test in mice

\begin{tabular}{|c|c|c|c|c|}
\hline \multirow[t]{2}{*}{ treatment } & \multirow[t]{2}{*}{ Dose } & \multicolumn{3}{|c|}{ Reaction time (sec) } \\
\hline & & $0 \mathrm{~min}$ & $30 \mathrm{~min}$ & $60 \mathrm{~min}$ \\
\hline control & & 10 & 8.5 & 8.77 \\
\hline Diclofenac sodium & $1.5 \mathrm{mg} / \mathrm{kg}$ & 14.53 & 22.54 & 14.53 \\
\hline Diclofenac sodium & $3 \mathrm{mg} / \mathrm{kg}$ & 17.21 & 26.11 & 17.21 \\
\hline Diclofenac sodium & $6 \mathrm{mg} / \mathrm{kg}$ & 15.39 & 30.00 & 15.39 \\
\hline Compound 3 & $1.5 \mathrm{mg} / \mathrm{kg}$ & 15.57 & 18.77 & 15.57 \\
\hline Compound 3 & $3 \mathrm{mg} / \mathrm{kg}$ & 19.12 & 24.53 & 19.12 \\
\hline Compound 3 & $6 \mathrm{mg} / \mathrm{kg}$ & 16.56 & 30.00 & 16.56 \\
\hline Compound 4 & $1.5 \mathrm{mg} / \mathrm{kg}$ & 14.97 & 19.76 & 14.97 \\
\hline Compound 4 & $3 \mathrm{mg} / \mathrm{kg}$ & 17.45 & 24.00 & 17.45 \\
\hline Compound 4 & $6 \mathrm{mg} / \mathrm{kg}$ & 15.46 & 21.87 & 15.46 \\
\hline Compound 5 & $1.5 \mathrm{mg} / \mathrm{kg}$ & 13.55 & 17.86 & 13.55 \\
\hline Compound 5 & $3 \mathrm{mg} / \mathrm{kg}$ & 15.33 & 22.09 & 15.33 \\
\hline Compound 5 & $6 \mathrm{mg} / \mathrm{kg}$ & 14.32 & 26.00 & 14.32 \\
\hline Compound 6 & $1.5 \mathrm{mg} / \mathrm{kg}$ & 16.00 & 20.54 & 16.00 \\
\hline Compound 6 & $3 \mathrm{mg} / \mathrm{kg}$ & 15.17 & 27.37 & 15.17 \\
\hline Compound 6 & $6 \mathrm{mg} / \mathrm{kg}$ & 19.00 & 27.44 & 19.00 \\
\hline
\end{tabular}

Inhibition of prostaglandin (PG) biosynthesis is now recognized as the major mechanism underlying the analgesic, , and anti-inflammatory property of NSAIDs so that In vivo acute anti-inflammatory activity of the synthesized final compounds was evaluated in rats to ascertain whether the synthesized compounds decreases carrageenin-induced increase in plasma prostaglandinE2 (PGE2) concentration. PGE2 has been established as a chemical mediator of inflammation as it is produced most abundantly in inflammation in contrast toits low production under physiological conditions (Girloy et al., 1999).

The results show that plasma PGE2 concentration in rats increased following carrageenin-induced inflammation but decreased when the inflammation was challenged with synthesized compounds and antiinflammatory drugs. The substantial increase in PGE2 in inflammation is attributable to expression of COX2(Raz, et al., 1988).

A selective COX-2 inhibitor, such as celecoxib, would therefore be expected to reduce inflammation or carrageenin-induced increase in plasmaPGE2 concentration to a lesser extent than non-selective inhibitor of COX-1 and COX-2 as However, clecoxib(selective COX-2 inhibitor) showed a significant decrease in PGE2 concentration due to the fact that although COX-2 is the only conjugate in disease, COX-2 is expressed in physiological conditions.

Enzyme-linked immune specific assay was used to measure plasma PGE2 concentration in the control and treated groups of rats. 


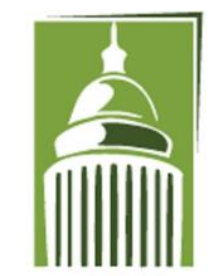

AR F

\section{Global Proceedings Repository \\ American Research Foundation}

ISSN 2476-017X

Available online at http://proceedings.sriweb.org

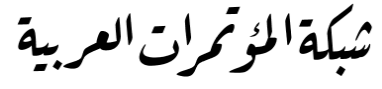

http://arab.kmshare.net/

Table 3: Percentage reduction in plasma PGE2 concentration (pg/ml) by different dose levels control and compounds 3-6

\begin{tabular}{|l||l||l|l||}
\hline Treatment & $\begin{array}{l}\text { Mean PGE Conc } \pm \\
\text { SEM }(\mathrm{pg} / \mathrm{ml})\end{array}$ & P value & $\begin{array}{l}\text { Percent of } \\
\text { inhibition } \\
\%\end{array}$ \\
\hline $\begin{array}{l}\text { Control } \\
\text { carrageenin) }\end{array} \quad$ (no & $1251 \pm 82.4$ & & \\
\hline $\begin{array}{l}\text { Control } \\
\text { carrageenin) }\end{array} \quad$ (with & $1805 \pm 124.6$ & & \\
\hline Diclofenac & $318 \pm 21.5$ & & 82.38 \\
\hline Compound 3 & $598 \pm 34.7$ & & 66.86 \\
\hline Compound 4 & $441 \pm 29.4$ & $\mathrm{P}<0.01$ & 75.56 \\
\hline \hline Compound 5 & $333 \pm 20.9$ & $\mathrm{P}<0.01$ & 81.55 \\
\hline Compound 6 & $336 \pm 18.7$ & $\mathrm{P}<0.01$ & 81.38 \\
\hline Celecoxib & $668 \pm 12.2$ & $\mathrm{P}<0.01$ & 62.99 \\
\hline
\end{tabular}

\section{Molecular docking}

was applied to understand the molecular interaction of synthesed compondd with with $\mathrm{COX}-1$ and COX2. 2-(1,1'-biphenyl-4-yl)propanoic acid and SC-558 which were co-crystallized in the structure of $1 \mathrm{Q} 4 \mathrm{G}$ and $1 \mathrm{CX} 2$, respectively, were extracted and redocked into their original binding pockets. The RMSD values resulted from these ligands redocking were $1.38 \AA$ and $0.94 \AA$ respectively for flurbiprofen and SC-558, which were less than $2.0 \AA$, a value typically used in evaluating the success of docking indicating the docking methods were valid. Ligands are visualized by stick and ball model. Green lines indicates hydrogen bonds which are formed between ligand and the amino acid residues in the binding pocket of COX-2

Docking Flurbiprofen in the long hydrophobic channel of the proposed active site of PGHS shows the carboxylic acid group of Flurbiprofen located in a favorable position for interacting with the guanidinium group of Arg120 (Figure 4). 


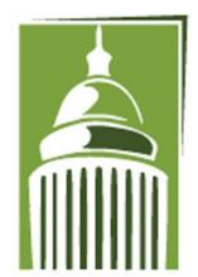

AR F

\section{Global Proceedings Repository \\ American Research Foundation}

ISSN 2476-017X

Available online at http://proceedings.sriweb.org

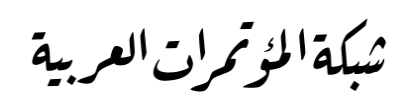

http://arab.kmshare.net/

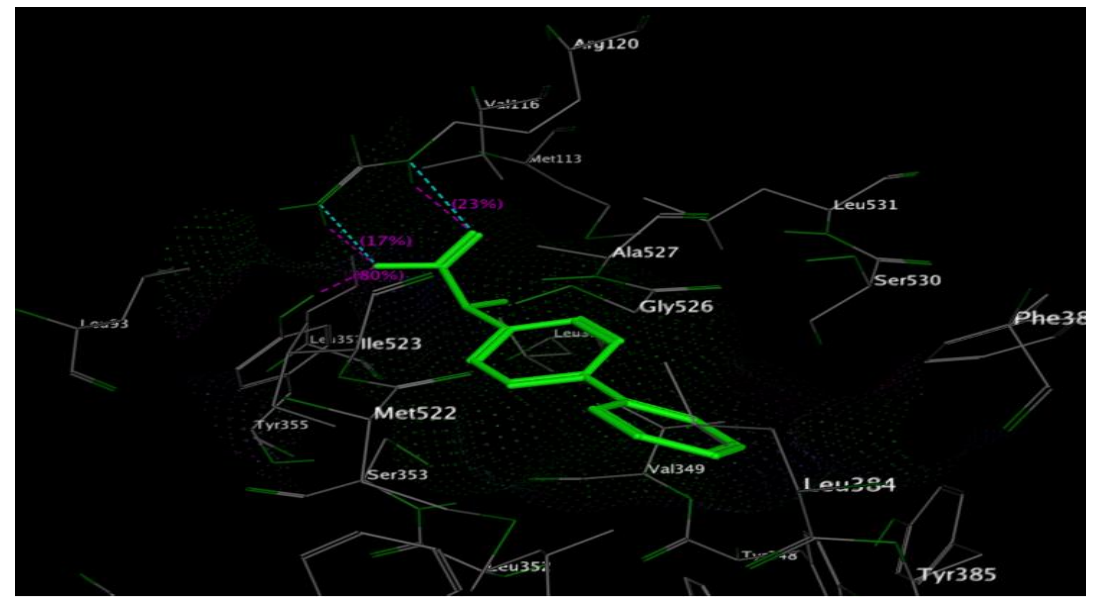

Figure 4:Docking of 2-(1,1'-biphenyl-4-yl)propanoic acid into the binding site of COX-1

The estimated free energy of binding using these docking conditions for SC-558 binding to $\mathrm{COX}-2$ was $-11.60 \mathrm{kcal} / \mathrm{mol}$ which was slightly different from thevalue from the literature $(-11.35 \mathrm{kcal} / \mathrm{mol})$.

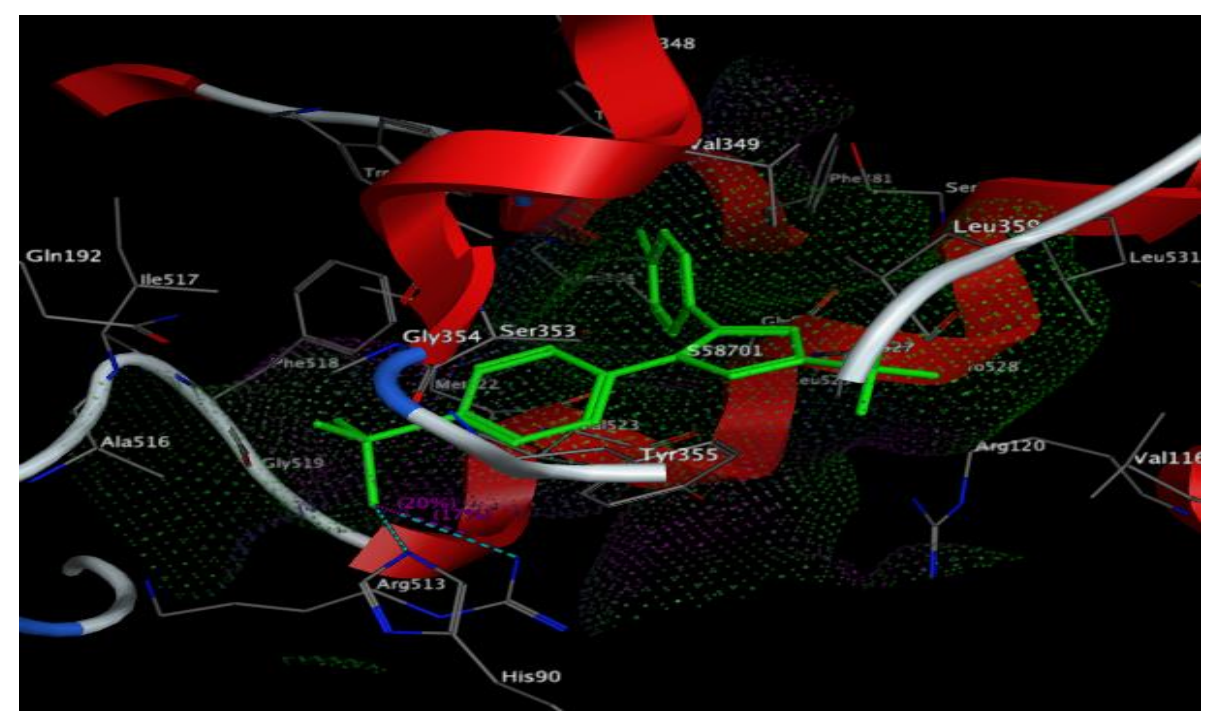

Figure 5: Docking of SC558 into the binding site of COX-2

COX-2 form hydrogen bonding with compound 3 at Arg120 and Ser530 While COX-1 forms don't made hydrogen bonding or made one at as Tyr 355 adopt an orientation similar to that of SC-558 inside the 


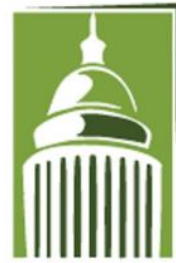

AR F

\section{Global Proceedings Repository}

American Research Foundation

ISSN 2476-017X

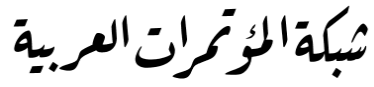

http://arab.kmshare.net/

Available online at http://proceedings.sriweb.org

COX-2 active site. In the active site, there are some moderate hydrogen-bonding interactions observed between residues and the ligands as shown in figures 6 and 7 .

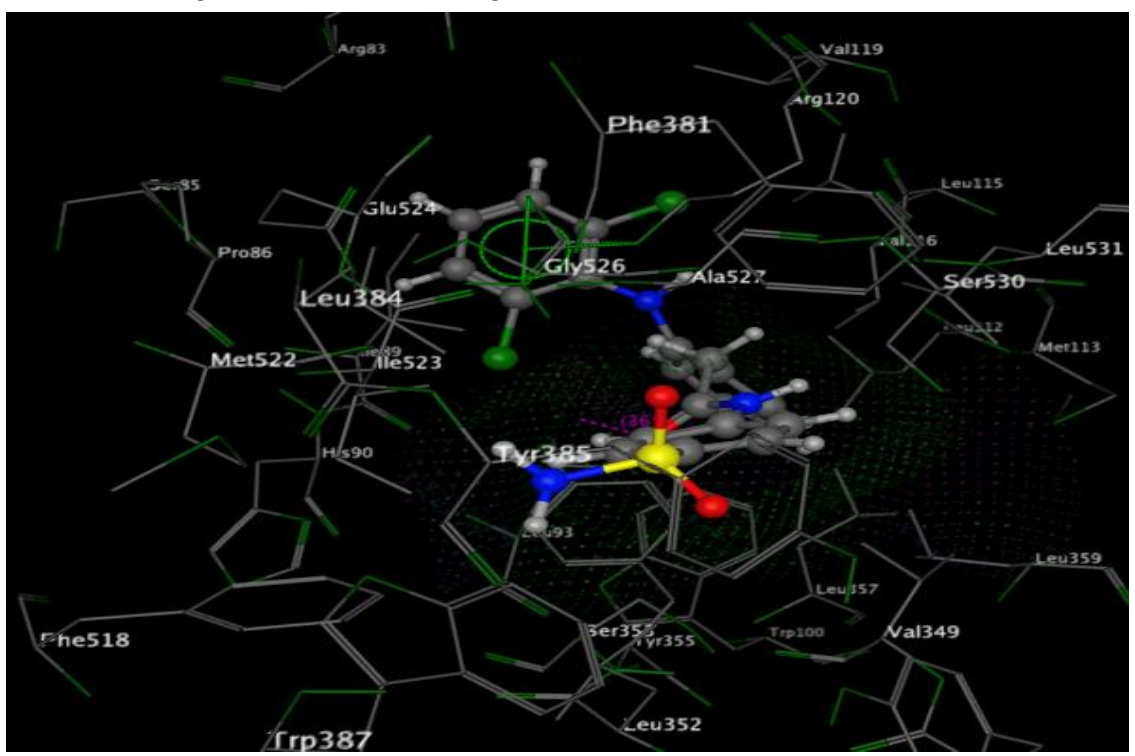

Figure 6 : docking compound 3 into the binding site of cox 1

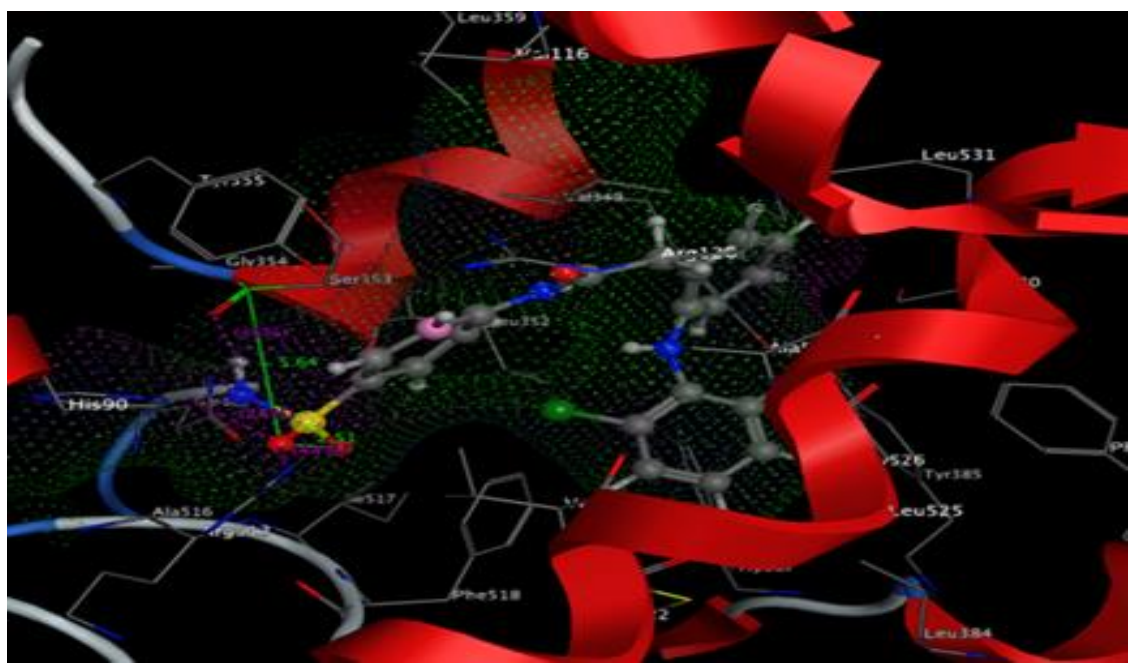

Figure 7: docking compound 3 into the binding site of COX-2 


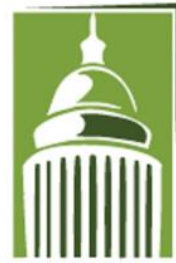

AR F

\section{Global Proceedings Repository}

American Research Foundation

ISSN 2476-017X

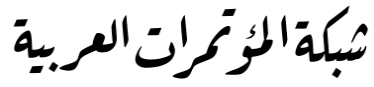

http://arab.kmshare.net/

Available online at http://proceedings.sriweb.org

Docking studies were carried out wherein these analogues were docked into the active sites of both COX-1 and COX-2 to analyze the receptor ligand interaction that confer selectivity for COX-2. Docking of compound 4 shows interaction between an aromatic ring only with COX-1 but form hydrogen bonding and interaction cation-aren with COX-2 at Arg120 and Arg 513.

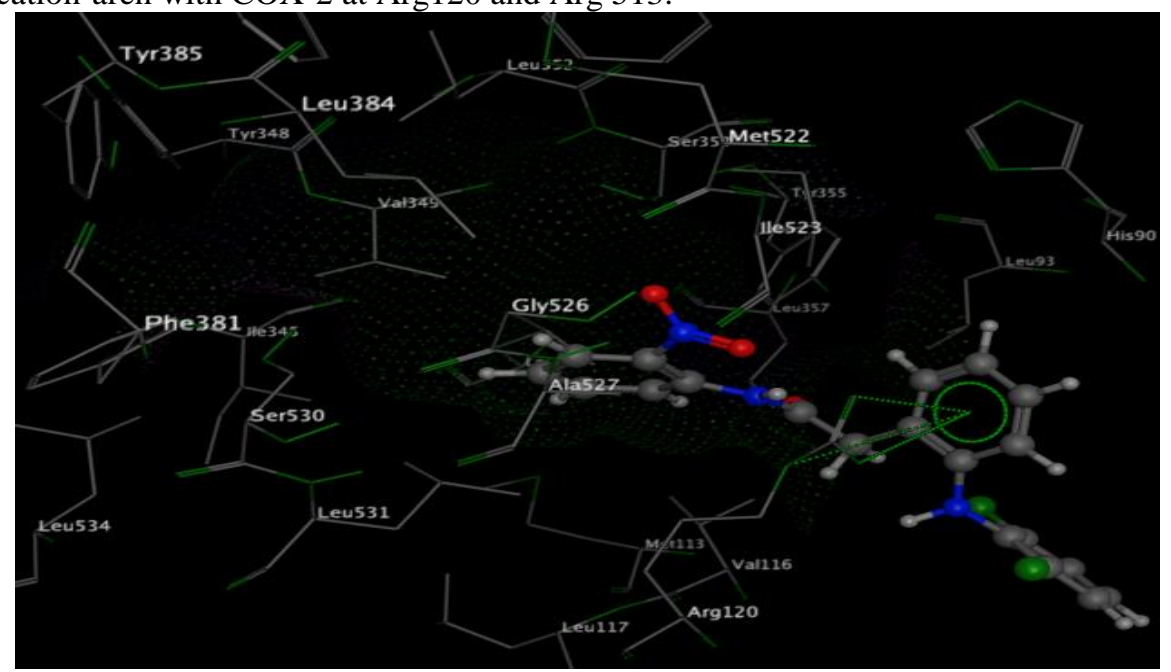

Figure 8: docking compound 4 into the binding site of $\operatorname{cox} 1$

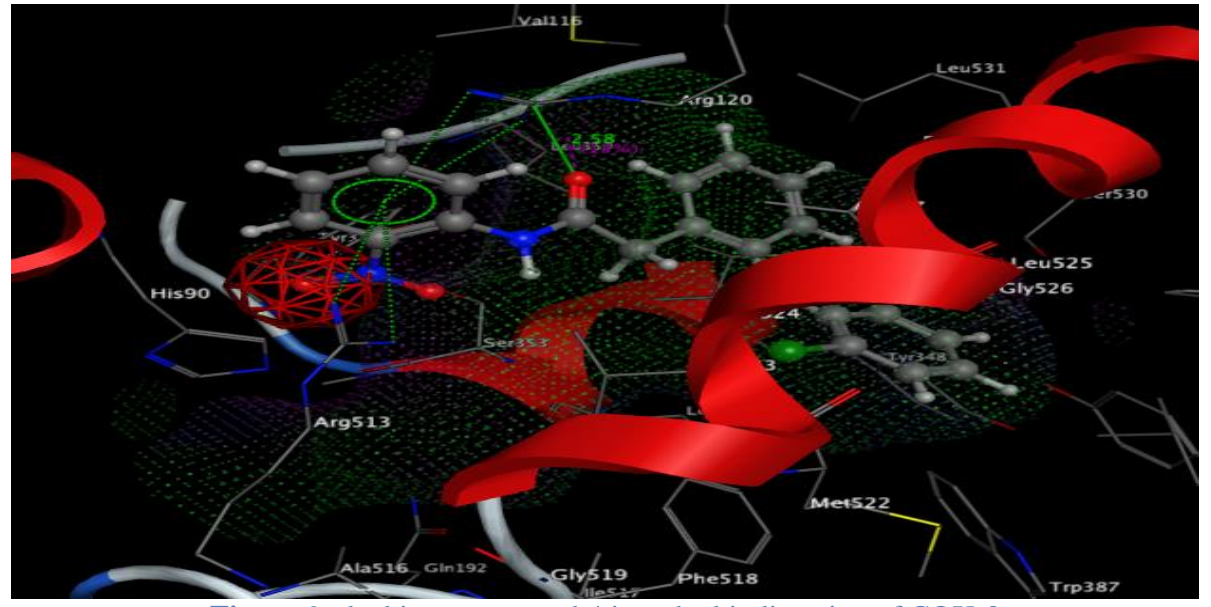

Figure 9: docking compound 4 into the binding site of COX-2

Docking studies of compounds 5 and 6 showed that modified compounds were have more affinity towards COX-2 as shown in figures 10,11 . 


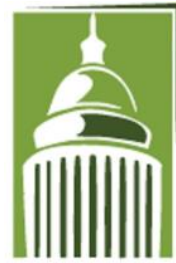

AR F

\section{Global Proceedings Repository}

American Research Foundation

ISSN 2476-017X

Available online at http://proceedings.sriweb.org

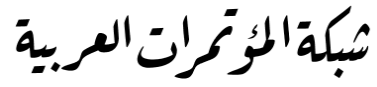

http://arab.kmshare.net/

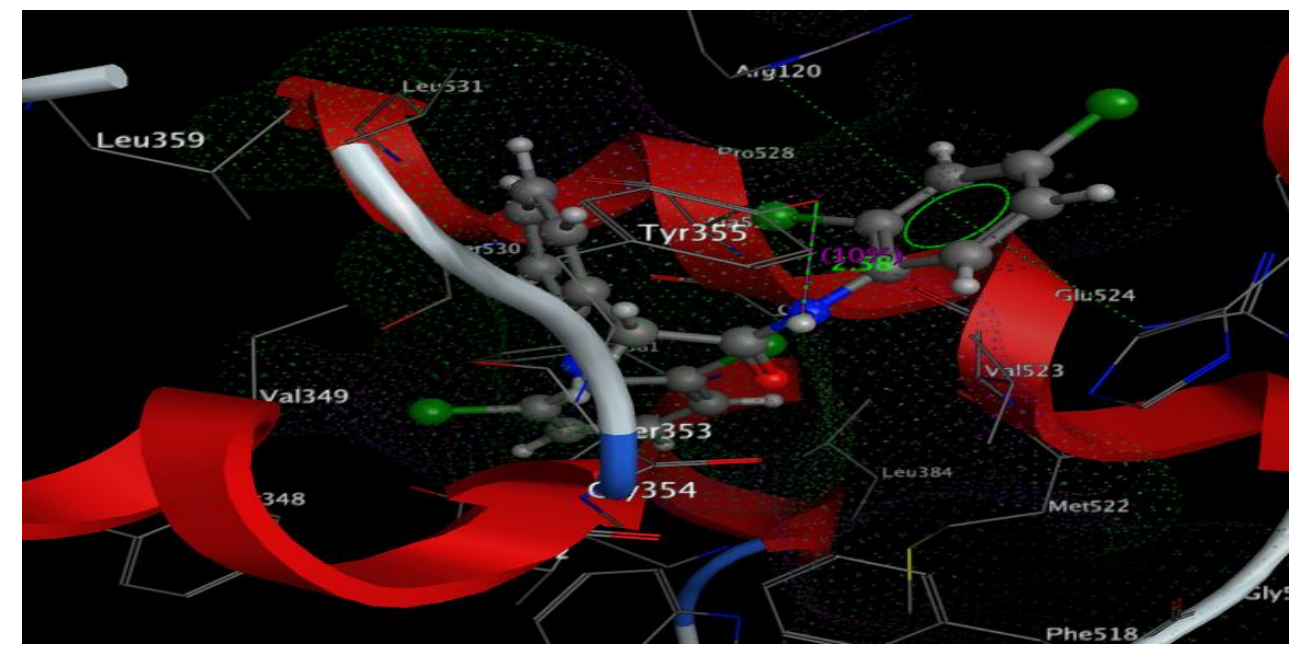

Figure 10: docking compound 5 into the binding site of COX-2

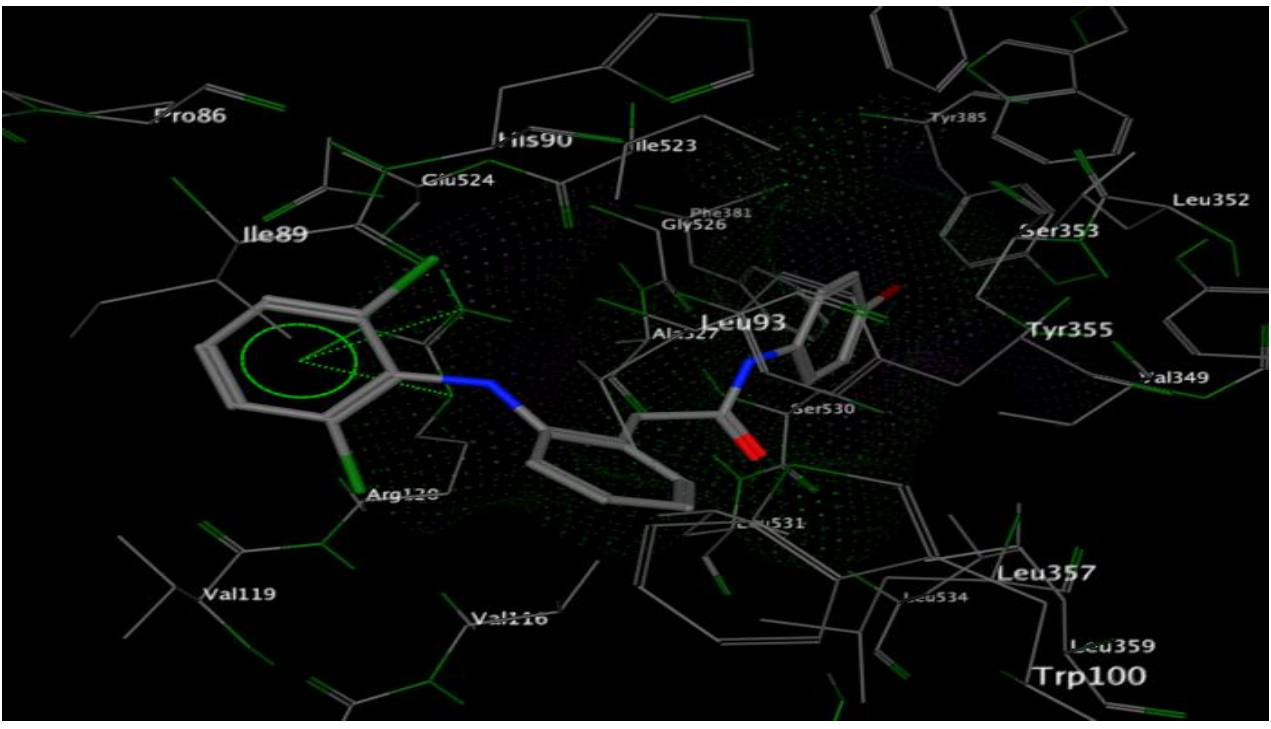

Figure 11 docking compound 6 into the binding site of COX-1 


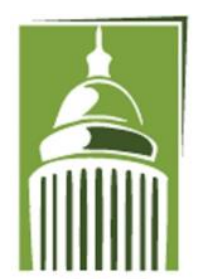

A R F

\section{Global Proceedings Repository \\ American Research Foundation}

ISSN 2476-017X

Available online at http://proceedings.sriweb.org

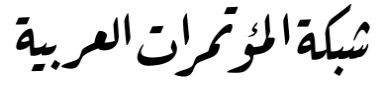

http://arab.kmshare.net/

\section{Conclusions}

An in vivo anti-inflammatory study showed that the incorporation of different amines (sulphanilamide, Onitroaniline, 2,4 dinitroaniline, P-bromoaniline) into well-known NSAID diclofenac sodium maintained or increase the anti-inflammatory activity. The results of docking studies was showed that modified compounds were have more affinity towards COX-2 .

\section{References}

Amresh G., Zeashan H., Rao C. V. and Singh P. N. (2007). Prostaglandin mediated anti-inflammatory and analgesic activity of Cissampelos pareira. Acta Pharm. Sci. 49: 153-160.

Banerjee P. K. and Amidon G. L. (1981). Physicochemical property modification strategies based on enzyme substrate specificities I: rationale, synthesis, and pharmaceutical properties of aspirin derivatives. $J$ Pharm Sci. 70(12):1299-1303.

Cavasotto C. N. and Abagyan R. A. (2004) . Protein flexibility in ligand docking and virtual screening to protein kinases. J. Mol. Biol. 12: 209- 225.

Chandrasekharan N.V. , Dai H. , Roos K.L., et al. (2002). COX-3, a cyclooxygenase-1 variant inhibited by acetaminophen and other analgesic/antipyretic drugs: cloning, structure, and expression. Proc Natl Acad Sci U S A .99(21):13926-13931.

Collignon B., Schulz R., Smith J.C. (2011). Task-parallel message passing interface implementation of Autodock4 for docking of very large databases of compounds using high-performance super-computers. J Comput Chem. 32: 1202-09.

FitzGerald G.A. (2004) . Coxibs and Cardiovascular Disease. N Engl J Med 351,1709-1711.

Fitzgerald G.A. and Patrono C. (2001). The coxibs, selective inhibitors of cyclooxygenase-2. N Eng J Med. 345:433-442.

Furniss B.S., Hannaford A.J., Smith P.W.C. and Tatchell A.R.(1989) Vogel's textbook of practical organic chemistry (5th Ed.). Longman, New York. 916 .

Girloy D.W. , Colville-Nash P.R., Willis D. , Chivers J., Paul-Clarke M.J., and Willoughby D.A.(1999). Inducible cyclooxygenase may have anti-inflammatory properties, Nat. Med.5(6):621-622

Guo Q. , Wang L.H., Ruan K.H.and Kulmacz R.J. (1996). Role of Val509 in timedependent inhibition of human prostaglandin $\mathrm{H}$ synthase-2 cyclooxygenase activity by isoform-selective agents. J. Biol. Chem. 271: 19134-19139

Ivković TC. (2010). Cyclooxygenase Isoforms in Tumorigenesis. Period boil. 112(4) :441-449. 


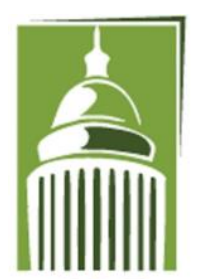

A R F

\section{Global Proceedings Repository \\ American Research Foundation}

ISSN 2476-017X

Available online at http://proceedings.sriweb.org

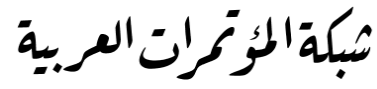

http://arab.kmshare.net/

Kamble P.S., Palatty P.L. and Kamble S.(2012). Comparative study of anti-inflammatory effects of rosiglitazone and pioglitazone with diclofenac sodium in carageenan induced rat hind paw oedema. International J. of Basic and Applied Medical Sciences. 2(1):1-7.

Koppen H. (2009). Virtual screening: What does it give us? Curr .Opin Drug Disc Dev. 12: 397-407 .

Luong C., Miller A., Barnett J., Chow J., Ramesha C. and Browner M.F. (1996). Flexibility of the NSAID binding site in the structure of human cyclooxygenase-2. Nat Struct Biol;3(11):927-933.

Maleki-Dizaji N., Fathiazad F. and Garjan A.(2007). Antinociceptive properties of extracts and two Flavonoids isolated from leaves of Danae racemosa. J. Arch. Pharm. Res. 30(12): 1536-1542.

Mukherjee D., Nissen, S.E. and Topol, E.J.(2001). Risk of Cardiovascular Events Associated With Selective COX-2 Inhibitors. JAMA. 286, 954-959.

Otto J.C., Smith W.L. (1995). Prostaglandin endoperoxide synthases-1 and -2. J. Lipid Mediat. Cell Signal. 12:139-56.

Plummer J.L., Cmielewski P.L., Gourly G.K., Owen H. and Cousins M.(1996). Assessment of antinocipetive drug effects in the presence of impaired motor performance. J Pharmacol Meth. 26:79.

Prempeh A.B. and Mensah-Attipoe J.(2008). In Vivo Inhibition Of Prostaglandin E2 Production By Crude Aqueous Extract Of The Root Bark Of Zanthoxylum Xanthoxyloides. Ghana Medical Journal. 42(2):85-88.

Rao P. and Knaus E.(2008). Evolution of Nonsteroidal Anti-Inflammatory: (NSAIDs) Cyclooxygenase (COX) Inhibition and Beyond. J Pharm Pharmaceut Sci. 11 (2): 81s-110s.

Raz A., Wyche A. and Siegel N. (1988). Regulation of fibroblast cyclooxygenase synthesis by interleukin1. J. Biol. Chem. 263:3022-3028.

Schoichet B.K. (2004). Virtual screening of chemical libraries. Nature . 43: 862-65.

Sharma S.K., Al-Hourani B. J. and Wuest M. (2012). Synthesis and evaluation of fluorobenzoylated di- and tripeptides as inhibitors of cyclooxygenase-2 (COX-2). Bioorganic \& Medicinal Chemistry. 20: 2221-2226.

Sharma V., Laxmi V. and Chauhan S. (2012) Cyclooxygenase-3: A Review. Am. J. PharmTech Res. 2:236-242.

Smith W.L., DeWitt D.L. and Garavito M. (2000). Cyclooxygenases: Structural, Cellular and Molecular Biology. Annu. Rev. Biochem. 69, 146-182.

Smith W.L., Garavito R.M., DeWitt D.L. (1996). Prostaglandin endoperoxide H synthases (cyclooxygenases)-1 and -2. J Biol Chem . 271(52):33157-33160. 


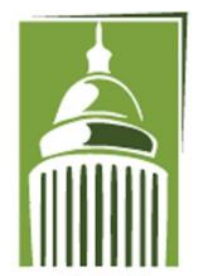

AR F

\section{Global Proceedings Repository \\ American Research Foundation}

ISSN 2476-017X

Available online at http://proceedings.sriweb.org

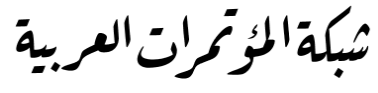

http://arab.kmshare.net/

Smith W.L., Langenbach R. (2001). Why there are two cyclooxygenaseisozymes? J Clin Invest 107(12): 1491-1495.

Somvanshi R.K, Kumar A. and Kant S. (2007). Surface plasmon resonance studies and biochemical evaluation of a potent peptide inhibitor against cyclooxygenase-2 as an anti-inflammatory agent. Biochemical and Biophysical Research Communications. 361:37-42.

Turini M.E. and DuBois R.N. (2002). CYCLOOXYGENASE-2: a therapeutic target," Annual Review of Medicine, vol. 53. 35-57.

Vogel H.G. and Goethe J.H .(Eds.).(2002) : Drug discovery and evaluation. pharmacological assays ( $2^{\text {nd }}$ ed). Springer-Verlag. Berlin Heidelbers. 751.

Winter C.A., Risley E. and Nuss G. Carrageenan-induced edema in hind paws of the rat as an assay for anti-inflammatorydrugs. Proc. Soc. Exp. Biol. Med. 1962;111: pp 544-547.

Winter C.A., Risley E.A. and Nuss G.(1963) . Antiinflammatory and antipyretic activities of indomethacin 1-(p chlorobenzoyl)-5-methoxy-2-methyl-indole-3-acetic acid. J Pharmacol Exp Ther. 141:369-376.

Woolfe G. and McDonald A.D. (1994). Evaluation of the analgesic action of pethidine hydrochloride (Demerol). J. Pharmacology and Experimental Therapy. 70: 300-307. 